17. Gharbi, G., Ben Alaya, M., Diop, C., Exposito, E. (2012). AODA: An autonomic and ontology-driven architecture for serviceoriented and event-driven systems. Proceedings of the Workshop on Enabling Technologies: Infrastructure for Collaborative Enterprises WETICE, 3, 72-77. doi: http://doi.org/10.1109/wetice.2012.84

18. The Java ${ }^{T M}$ Tutorials. Available at: https://docs.oracle.com/ javase/tutorial/ Last accessed: 24.03.2019

19. Apache Jena - Jena tutorials. Available at: https://jena.apache org/tutorials/index.html Last accessed: 24.03.2019

20. Zhang, Y. (2015). Research on Efficient SPAROL Query Processing for RDF Data. Proceedings of the 2015 2nd International Workshop on Materials Engineering and Computer Sciences, 476-482. doi: http://doi.org/10.2991/iwmecs-15.2015.94

21. OpenLink Virtuoso Universal Server: Documentation (2007). Available at: http://docs.openlinksw.com/virtuoso/

22. Bibichkov, I., Sokol, V., Shevchenko, O. (2017). Ontologica knowledge bases productivity optimization through the use of reasoner combination. Eastern-European Journal of Enterprise Technologies, 5 (2 (89)), 49-54. doi: http://doi.org/10.15587/ 1729-4061.2017.112347

Bibichkov Igor, Assistant, Department of Artificial Intelligence, Kharkit National University of Radio Electronics, Ukraine, ORCID: http:// orcid.org/0000-0003-1424-6960,e-mail: bibi4kov@gmail.com

Sokol Vadym, Postgraduate Student, Department of Artificial Intelligence, Kharkiv National University of Radio Electronics, Ukraine, ORCID: http://orcid.org/0000-0003-2461-3453, e-mail: sokol@sw-expert.com

Shevchenko Oleksandr, PhD, Associate Professor, Department of Artificial Intelligence, Kharkiv National University of Radio Electronics, Ukraine, ORCID: http://orcid.org/0000-0002-0068-4698, e-mail: shevchenko@sw-expert.com

\title{
Dahahian D. DETERMINATION OF INTELLECTUAL ACTIVITY IN SOLVING THE PROBLEMS OF BANK FUNCTIONING OPTIMIZATION
}

Об'єктом дослідження є процес функиіонування комерційного банка. Одним з найбільш проблемних місць $\epsilon$ оптимізація роботи банка згідно з вимогами клієнтів в умовах обмежених ресурсів, тобто, як потрібно розподілити певну суму інвестицій по різним напрямкам діяльності банка оптимальним чином. Під иим слід розуміти максимальну задоволеність клієнтів процесом функціонування банка. Також слід визначати важливість напрямків діяльності в залежності від зворотнього зв'язку з клієнтами - збираючи клієнтську інформацію, таку як скарги, побажання, результати опитів та інше. Такі дані не є інтелектуальними, їх треба формалізувати та на иій основі побудувати стратегію функиіонування банка на певний період часу.

В ході дослідження було використано висхідний підхід до створення систем штучного інтелекта. На основі не інтелектуальних даних (підсистеми банка, клієнтські дані, статистика) визначається інформація для побудови інтелектуальної діяльності стосовно прийняття рімень щодо оптимізації процеса функиіонування банка в иілому, як єдиної системи, тобто побудови оптимальної стратегії діяльності банка.

В результаті дослідження отримано проект інтелектуальної системи, яку призначено для побудови оптимальної стратегії діяльності в умовах обмежених ресурсів. Для заповнення бази знань иієї системи проведено структурування та формалізацію знань. Оптимальним варіантом для иього дослідження було визнано формально-логічну модель на основі побудови предикатів першого порядку.

Завдяки иьому забезпечується можливість реалізації інтелектуальної системи для вирішення проблеми розподілу внутрішніх інвестицій банка оптимальним шляхом, тобто, з максимальним підвищенням рівня задоволеності клієнтів. Використання иієї системи на практиці має допомогти керівництву банка розподілити певний обсяг внутрішніх інвестицій у напрямках діяльності банка оптимальним шляхом, керуючись побажаннями клієнтів.

Ключові слова: ефективні відносини «банк-клієнт», інтелектуальна система, оптимізація функціонування банка, розподіл інвестищій.

\section{Introduction}

To date, artificial intelligence systems are already used in banking [1-3]. This allows to save time manual processing of some banking information, to reduce the amount of the same type of work that bank employees perform and so on.
Standard financial products and services designed for a wide range of consumers - this is yesterday. The modern client needs the personified conditions for deposits, loans and other offers. To realize this without an individual approach is impossible. Here, the banks come to the aid of artificial intelligence. 
Now every financial institution develops and offers customers $10-20$ products. A team of professional people has been working on them for a long time. However, if it is necessary to generate hundreds of thousands of personalized offers, then it isn't possible to do without using the AI system.

According to statistics, at present, every person has 2-5 electronic devices, through which it goes online, uses instant messengers and social networks. Naturally, a large amount of data for all users remains in the virtual web. The artificial intelligence algorithm is able to collect information on the client, analyze and generate an individual offer.

The main areas of application of artificial intelligence systems in banking are chatbots and personal virtual assistants, that is, financial consultants.

Table 1 shows examples of the use of artificial intelligence systems in the operation of banks.

Tahle 1

Examples of the use of artificial intelligence in banking

\begin{tabular}{|c|c|c|l|}
\hline No. & Bank & State & $\begin{array}{c}\text { Functions of artificial intelligence systems } \\
\text { in bank activities }\end{array}$ \\
\hline 1 & $\begin{array}{c}\text { JP } \\
\text { Chasan }\end{array}$ & USA & $\begin{array}{l}\text { «Lontract Intelligence» system. Purpose - the } \\
\text { analysis of legal documents and the finding of } \\
\text { significant data and incidents in them. } \\
\text { «Emerging Opportunities Engine» system. Pur- } \\
\text { pose - identifying those customers who are } \\
\text { most suitable for the following offers and } \\
\text { promotions }\end{array}$ \\
\hline 2 & $\begin{array}{l}\text { Wells } \\
\text { Fargo }\end{array}$ & USA & $\begin{array}{l}\text { Artificial intelligence chat bot based on Face- } \\
\text { book Messenger, with which the client can } \\
\text { obtain information about its account and reset } \\
\text { its password }\end{array}$ \\
\hline 3 & $\begin{array}{l}\text { Bank of } \\
\text { America }\end{array}$ & USA & $\begin{array}{l}\text { Erica is a chat robot using «cognitive messages } \\
\text { and predictive analytics». Main purpose - fi- } \\
\text { nancial recommendations to clients [1] }\end{array}$ \\
\hline 4 & UB5 & 5weden & $\begin{array}{l}\text { Alexa is a financial advisor built into Acoustic } \\
\text { Echo devices. Analysis of the situation in world } \\
\text { financial markets [2] }\end{array}$ \\
\hline 5 & $\begin{array}{l}\text { Sber- } \\
\text { bank }\end{array}$ & $\begin{array}{c}\text { Fussian } \\
\text { Federation }\end{array}$ & $\begin{array}{l}\text { iPavlov is research project for an applied } \\
\text { purpose: the ability to build dialogue systems } \\
\text { that are able to maintain a meaningful dialogue } \\
\text { with the user [3, 4] }\end{array}$ \\
\hline
\end{tabular}

Based on the results of the analysis of the functions of artificial intelligence systems (Table 1), the main directions of the use of knowledge of information resources in addressing the issues of effective activity of banks are determined. This is providing recommendations to the user on the financial situation (in the country, in the world, etc.), or identifying those customers who can, with the maximum probability of consent, make some kind of service or offer. Other areas - forecasting further activities, marketing activities, for credit customer service and more. The cognitive abilities of the artificial intelligence system (AIS) (the client communicates with such systems in a language as close to natural as possible) are used to recognize and identify by physiological data: voice, fingerprints, DNA.

Thus, the topic of the use of intelligent systems in banking is relevant, as evidenced by the already existing examples of the operation of such systems, and the active development of this area in large commercial banks with a worldwide reputation.

\section{The object of research and its technological audit}

The object of this research is the functioning of a commercial bank. An indicator of the effectiveness of this process is the level of customer satisfaction with the bank's services. Such data is collected by feedback systems, statistics, surveys and more. All these data are not intellectual, therefore it is difficult to use them to build an optimal bank development strategy (optimizing the process of its functioning). Such work is usually carried out by qualified specialists from the departments of methodology, analysis and risk.

The most problematic stage of such work is usually the formalization and structuring of data that is received from customers. Also a problem is the synthesis of knowledge from this data. Therefore, an intelligent system will be built to help determine the optimal development strategy.

\section{The aim and objectives of research}

The aim of research is building a project of an intellectual system to determine the optimal development strategy of the bank in the conditions of limited resources.

To do this, there are the following steps:

1. To determine the main criteria for customer satisfaction - how the client evaluates the functioning of the bank is a priority for it.

2. To collect data from respondents: statistics of complaints, appeals to customer support, customer survey results.

3. To analyze the existing approaches to assessing the functioning of the bank by customers.

4. To build a project of an intellectual system that the bank management can use to help build an optimal bank development strategy.

\section{Research of existing solutions of the problem}

Among the main directions of solving the problem of optimizing the functioning of the bank in conditions of limited resources identified in the resources of the world scientific periodicals, a number of publications can be singled out. But most of them are tied to specific regions of the study, taking into account local characteristics, and cannot be applied on the Eastern European banking market. Also, almost all works use the SERVQUAL model as a mathematical apparatus. For example, in [5], the problem of quality of service management in North Korean banks is considered. This work has the main purpose of considering the quality of banking services focused on Asian countries. Work [6] is oriented to the Vietnamese market, and it mainly addresses customer satisfaction with the deposit service. Work [7] considers the degree of customer satisfaction of Turkish banks. In a scientific work [8], trends in the development of the banking sector in Bangladesh are studied. Closer to the Ukrainian market works [9, 10] are devoted to assessing the reliability of a commercial bank by customers, and the continuous process of managing the quality of banking services. These studies were conducted in the Russian Federation. But all of the above works are devoted mainly to the definition of criteria for evaluating a bank by customers, quality management, and they do not consider the use of intelligent systems.

Multicriteria assessment is also considered in [11], but the work of the bank branch, and not of the bank as a whole, 
as a single system is evaluated. Works [12, 13] investigate the problems of increasing the attractiveness of a bank for customers, that is, how a bank can retain old customers and attract new ones, but they do not consider the problem of investment distribution. The work [14] gives more specific recommendations on building a bank development strategy, but also does not provide a method for distributing investments. These works also do not highlight the use of intelligent systems in the banking sector. Therefore, all of the above labor is used to collect information about the main criteria for evaluating the bank by customers.

The work [15] is devoted to the use of expert systems and geographic information systems in solving the problem of developing a network of bank branches (determining the best location). But there is no consideration of the criteria for assessing the functioning of the bank by customers.

An expert system for assisting financial management is identified in [16]. However, this work is focused on the user of banking services, and not to build an optimal bank development strategy.

Thus, the results of literature analysis allow to conclude that the topics of assessing the functioning of the bank by customers and the use of intelligent (and expert) systems in banking are promising, but are considered independently of each other. Therefore, this work is devoted to combining these two topics: building an intelligent system project based on criteria for evaluating a bank by customers. And the main application of such a system is the distribution of domestic investments in an optimal way to increase customer satisfaction.

\section{Methods of research}

The system that will be developed in the process of work should be classified as an expert system, the knowledge base of which is built on the basis of customer feedback, surveys and other sources of information, reflects the experience of the bank and banking experts. This system is a decision support system. It will use soft calculations based on fuzzy logic (since the criteria for evaluating a bank are not clear). To build a hierarchy of criteria for evaluating a bank by customers, the Saaty pair comparison method and the hierarchy analysis method are used.

An intelligent system developed in the framework of this work to solve the problems of resource allocation to ensure stable banking-client relations is based on the main property of the Emerging Opportunities Engine system [3], that is, on the basis of client criteria it is determined which services (or properties of the bank) is not available, recommendations are given to determine the essential parameters of the bank's assessment. In this work, this aspect of the activity of AIS is used to develop a decision-making system for the allocation of investments according to such criteria in an optimal way. It is assumed that the cognitive abilities of the new system will not be developed: information from clients comes in an already formalized form. The ability to self-study is: depending on the responses of customers, which may vary, conclusions are made about the materiality of the criteria.

Fig. 1 shows the structure of the intelligent system.

Users are customers of the bank (that is, those who use banking services). Decision makers are management, the management of the bank.

The Bank Communication Systems module is designed to collect information from users using feedback systems and periodic surveys. Based on these data, the Intelligent Interface module draws conclusions about the degree of customer satisfaction and their assessment criteria of the bank. The decision inference unit formalizes the information received and places the knowledge base.

The knowledge base contains knowledge about the benefits of customers and the ways and factors by which they evaluate the quality of the bank.

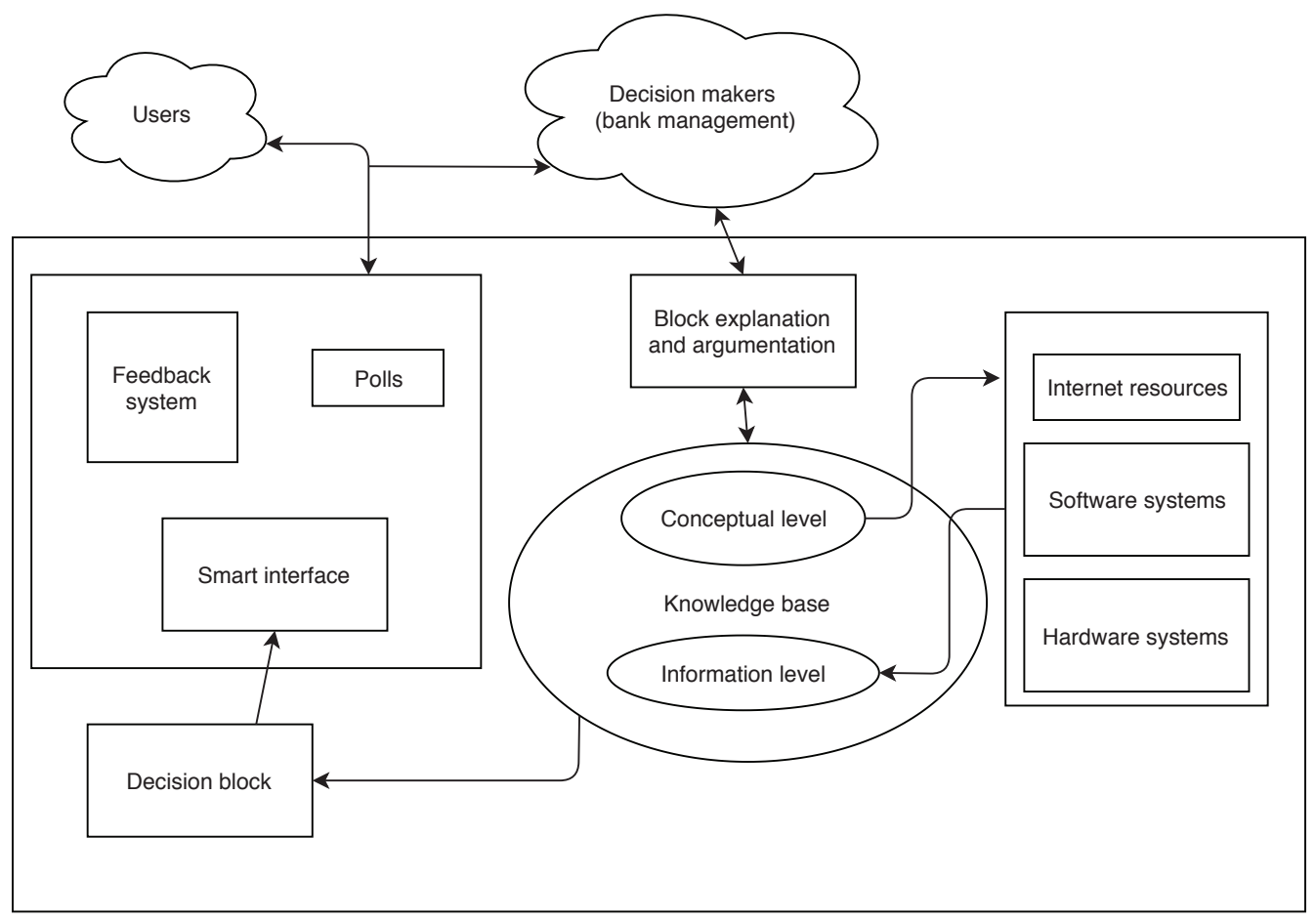

Fig. 1. The structure of the intellectual system 
In this work, the knowledge base is enriched by information from the hardware and software systems of the bank: ATMs, self-service terminals, mobile applications, web resources. These data fall into the relational database of the bank, and after processing by the logical inference unit of the decisions obtained by the knowledge.

The block of explanation and argumentation makes recommendations for improving the functioning of the bank, and provides these recommendations to decision makers. This unit also deals with forecasting: what will happen if investments are distributed in a certain way; what will happen if to do not take any actions and other situations that arise in the activities of the bank with customers.

Thus, the general structure of the intellectual system, which is presented in Fig. 1, is a general view of the proposed expert system. Let's consider some explanations regarding the scheme.

The logical conclusion block is for obtaining new facts based on a comparison of the source data from the working database and knowledge from the knowledge base. It contains the following procedures: $V$ - the procedure for selecting rules and facts from the database and knowledge base; $W$ - the procedure for performing actions corresponding to the obtained value of the fact.

In this system, the object of study is the process of functioning of the bank. It is advisable to monitor some indicators of the bank's activity over a specific period of time. This allows to establish a relationship between the degree of customer satisfaction depending on the values of the bank's performance indicators and external factors. This degree of satisfaction is the basis for continued service at this customer bank.

A specific example: monitoring the volume of a bank's loan portfolio during the period 2012-2018. The volume is monitored on a monthly basis, so the first days of all months of 2012-2018 will be a specific parametric set. They can be replaced by serial numbers $1-72$.

Each dimension is a definition of the total amount of loans to individuals and legal entities, the prospects for their return. These are all numerous variables; they are defined through clear observation channels. According to the values of these variables and external data (lending conditions, advertising campaigns, political situation in the country, etc.) is determined depending on the degree of customer satisfaction.

\section{Research results}

6.1. Expert system design. For system design, the methodology of «quick design» will be used, the general scheme of which is shown in Fig. 2.
The stage of problem identification - at this stage it is determined which problem the expert system will solve. In the framework of this work, this is an increase in the degree of customer satisfaction with minimal investment. It is advisable to solve this problem by means of an expert system, since the initial data is constantly changing. But almost the entire amount of data at any time is available in a formalized form, as it is based on statistics on the activities of the bank. Also the criteria for measuring customer satisfaction are conflicting. To solve strategic problems, it is advisable to involve experts, and for the regular solution of tactical tasks it is enough to use an expert system.

The first step is to answer the basic question: how is customer satisfaction measured? It is proposed to reformat the question: how does the client evaluate the level of banking services. And then decomposition of this problem is carried out. For this, in previous works, a model for assessing a bank by a client is built on the basis of the Saaty hierarchy analysis method [17], it is shown in Fig. 3.

The next stage of design is the acquisition of knowledge. This is the formation of an engineer's knowledge (of the person who will «learn» the system), an understanding of the subject area, basic knowledge, determination of basic facts to fill out the database.

At the stage of structuring knowledge, a hierarchical system of knowledge and the presentation of an expert are created. For this, the main objects of the subject area are determined. In this work, the main object that forms the degree of customer satisfaction is a group of criteria for evaluating a high-level bank, namely reliability, quality of service, and a range of services. Further, each criterion is a list of its parameters: for example, for reliability, this is the amount of the authorized capital, participation in the Deposit Guarantee Fund program, reputation among the population, the volume of deposits, etc.

In turn, each parameter has its own range of values. These areas provide in the form of various ways of displaying the applied parameters. For example, for the parameter «loan portfolio volume» it is a range of values from 0 to the average value of the loan portfolio of Ukrainian banks. For the parameter «own processing» is a logical function of truth (yes or no).

Next, the connection between the concepts is revealed. For example, the volume of the bank's deposits depends on the bank's participation in the Deposit Guarantee Fund program, the volume of the loan portfolio depends on the fact that the bank's leadership belongs to the political elite of the country, and so on.

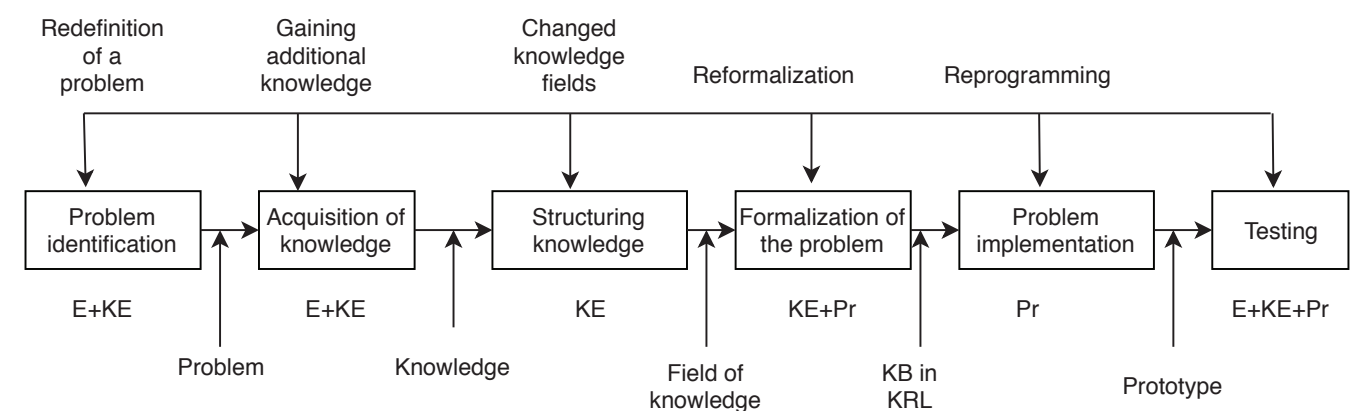

Fig. 2. The general design scheme of the expert system:

E - expert; KE - knowledge engineer; Pr - programmer; KB - knowledge base; KRL - knowledge representation languages 


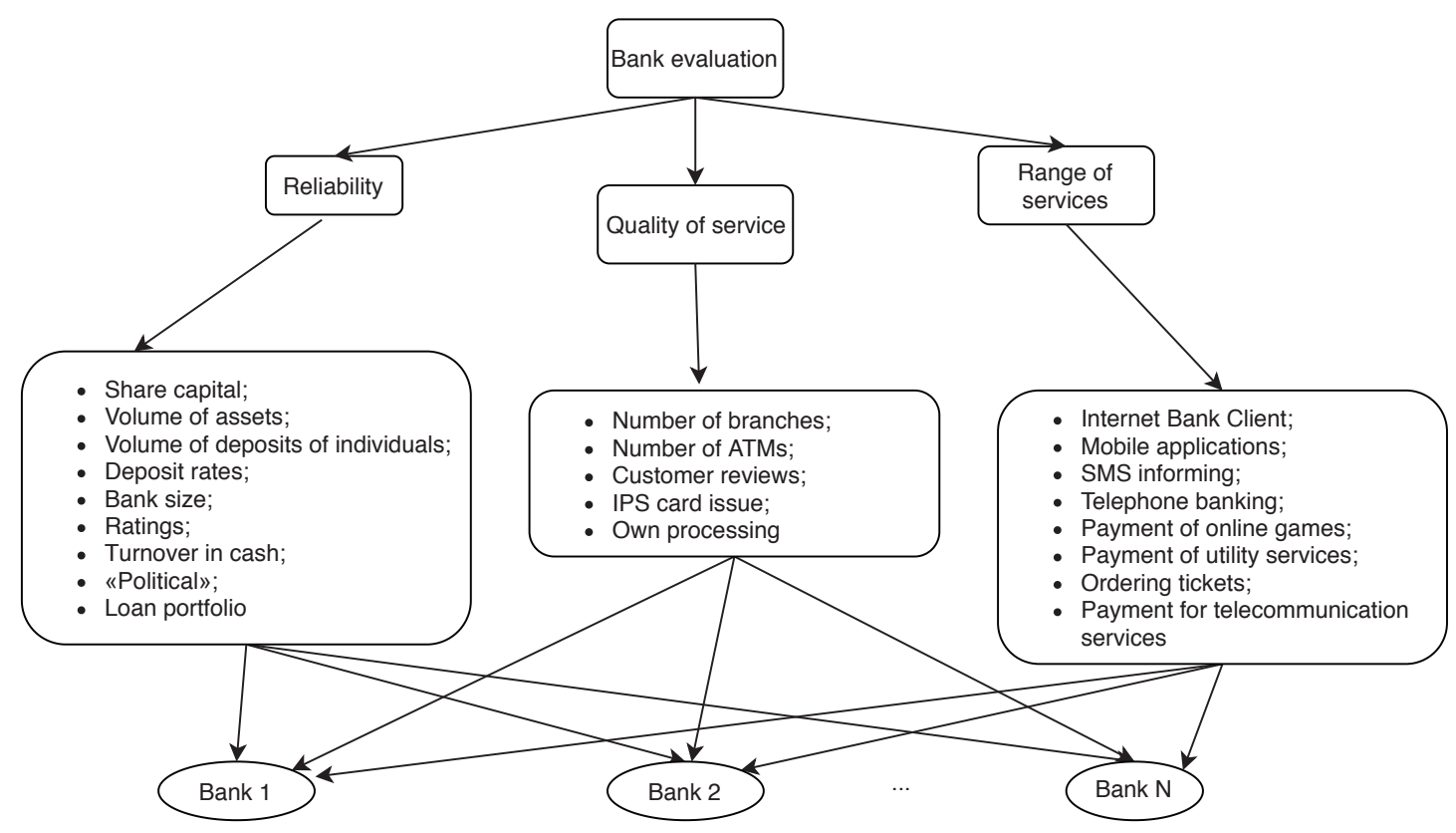

Fig. 3. Hierarchy of bank assessment criteria

It is proposed to take into account some specific features in addition, for example, the influence of external factors, such as crises, elections, possible «jumps» in the foreign exchange market, the international political environment and other factors that cannot be (or very difficult) to predict.

During the structuring of knowledge, the conceptual and functional structures of the subject area are determined. In Fig. 4, 5, an abridged example of the conceptual structure of the subject area of this work (input factors) is given. Table 2 contains a brief description of the functional structure of the subject area.

The next stage is the formalization of knowledge. As part of the work, a formal logical model of knowledge representation will be used to formalize knowledge.

The final steps - prototype implementation and testing - will not be considered in this work.

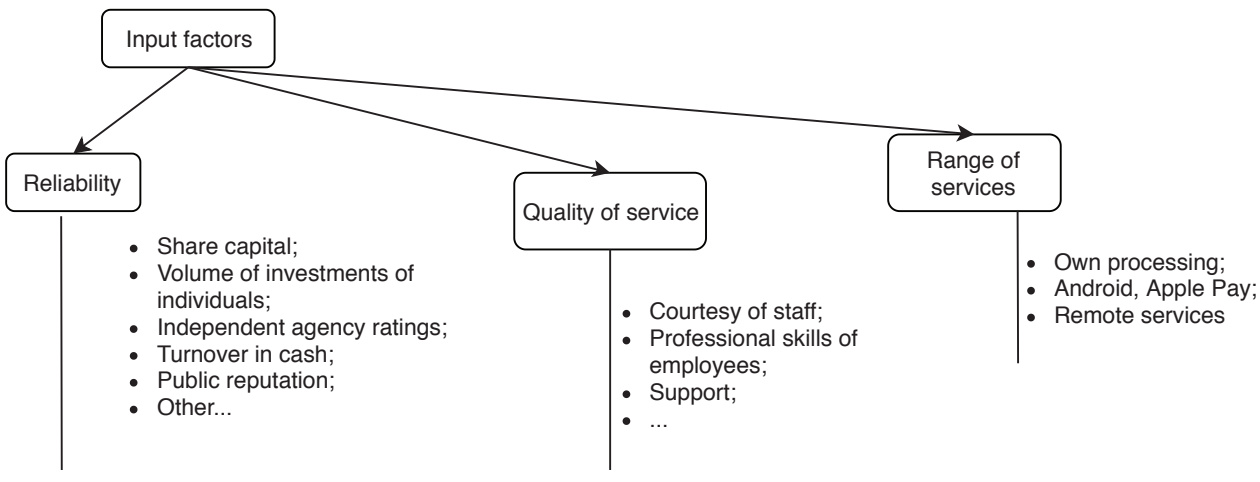

Fig. 4. The conceptual structure of the subject area (input factors)

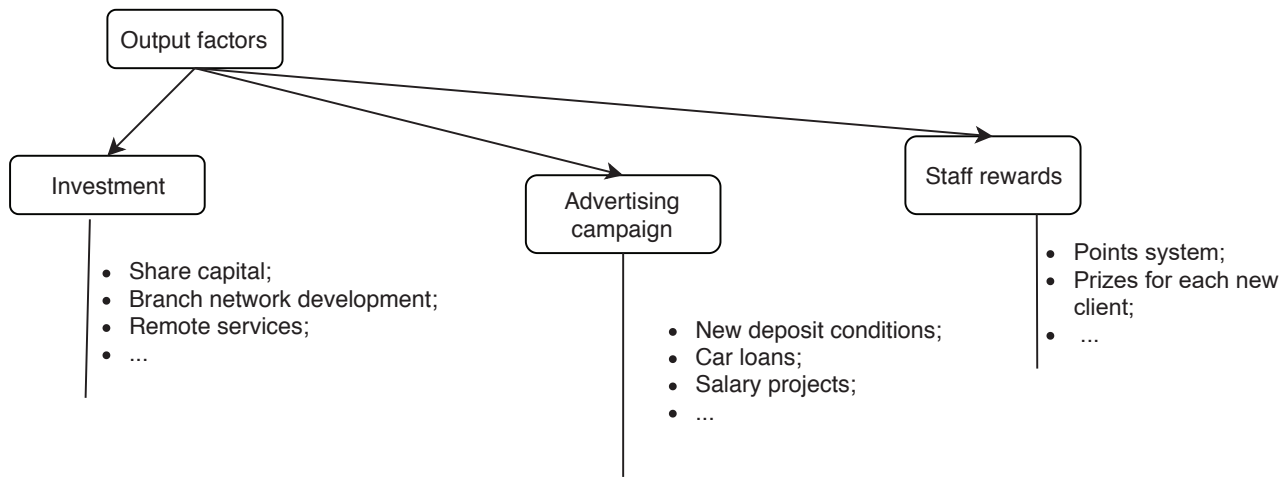

Fig. 5. The conceptual structure of the subject area (output factors) 
Functional structure of the subject area

\begin{tabular}{|c|c|c|c|c|c|}
\hline $\begin{array}{c}\text { The amount of the authorized } \\
\text { capital (mln. USD) }\end{array}$ & $\begin{array}{c}\text { Deposits volume } \\
\text { (mln. USD) }\end{array}$ & $\begin{array}{c}\text { Loan portfolio volume } \\
\text { (mln. USD) }\end{array}$ & $\begin{array}{c}\text { Remote services } \\
\text { (rating 0...9) }\end{array}$ & Advertising campaign & $\begin{array}{c}\text { Confidence } \\
\text { degree }\end{array}$ \\
\hline \multirow{3}{*}{$4-9$} & $1-2$ & $4-6$ & 6 & Deposits & 8 \\
\cline { 2 - 6 } & $2-3$ & $6-12$ & 7 & Deposits & 7 \\
\cline { 2 - 7 } & $>3$ & $>12$ & 7 & Deposits, new credit conditions & 8 \\
\hline \multirow{2}{*}{$9-20$} & $>3$ & $>8$ & Remote services & 5 \\
\hline \multirow{2}{*}{$20-30$} & $>4$ & $<8$ & 9 & Deposits & 7 \\
\cline { 2 - 7 } & $>4$ & $>8$ & 9 & New loan terms & 6 \\
\hline
\end{tabular}

6.2. Knowledge representation model. In formalizing knowledge, it is necessary to build their model. There are several attempts to classify knowledge representation models. Fig. 6 shows one of them [18].

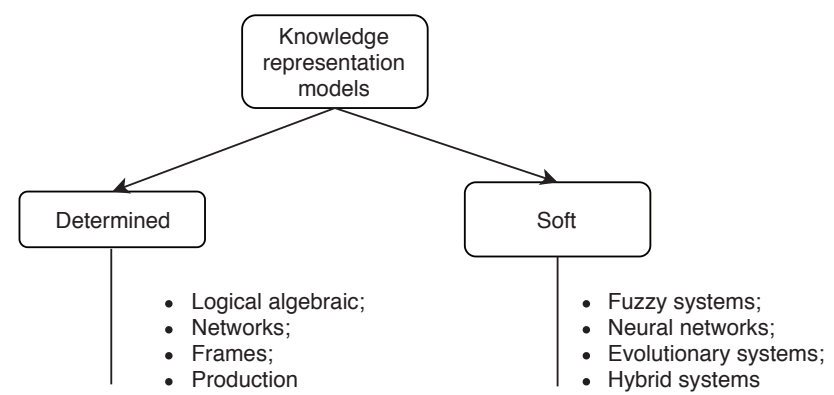

Fig. 6. Classification of knowledge representation models

For this research, the optimal option is a formal logical model [18, 19] of knowledge representation, which belongs to the class of deterministic models (a group of logical-algebraic). These models are based on first-order predicates. There is a finite, non-empty set of objects of a subject area. On this set with the help of interpreter functions, relationships between objects are established. Based on these connections, all the laws and rules of the subject area are built. The importance of the proper formation of the subject area is determined by its role in achieving the goals: if the presentation of the subject area is not correct, that is, the communication between the objects is not configured correctly, or not fully, then the correct performance of the system is at risk.

First-order predicate calculus is a formal language that is used to represent relationships between objects and to identify new relationships based on existing ones. The alphabet of the first order predicate calculus language includes variables, constants, predicates, logical operations, functions, quantifiers. The sentence constructions in the first-order predicate calculus language are governed by syntactic rules.

A term is a variable, constant, or the result of applying a function to a term, for example, $a, x, f(x)$. The parent language of the first-order predicate calculus is formulas that are defined as follows:

If $P$ is an $n$-predicate (a predicate of $n$ arguments) and $t 1, t 2, \ldots, t n$ - terms, then $P(t 1, t 2, \ldots, t n)-$ an atomic formula (atom).

Atom is a correctly constructed formula.

If $F 1$ and $F 2$ are atoms, then $F 1 \wedge F 2, F 1 \vee F 2, F 1 \rightarrow F 2$, \urcorner $F 1$ are also atoms.
If $F$ is a formula and $x$ is not a quantifier variable, the variables in $F \forall x(f), \exists x(f)$ are also atom.

To avoid ambiguity, formulas should be defined in which all variables are quantized, that is, connected by quantifiers.

This formula is called closed. A closed formula has one and only one true value [19].

To build models of a certain subject area, one should describe the known facts in the language of predicate logic. Using its results, build a system that is capable of building on the basis of existing facts, build some new proposals and answer the questions posed.

For a machine solution of the above problem, the method of automatic formation of discretion, or the deduction method, is used. At the same time, the following procedures are implemented:

- exclusion of signs of implication;

- restriction of the scope of the negation sign;

- rename variables;

- putting quantifiers at the beginning of the formula;

- exception of quantifiers and so on.

When automating the derivation of evidence using predicate calculation methods, it is necessary to determine a number of procedures for choosing rules to avoid a «combinatorial explosion» and to ensure a non-monotonic reasoning. The solution to the problem is the creation of declarative programming languages (Prolog).

Programming in such languages includes the following steps:

- statement of some facts about the objects and the relationship between them;

- definition of certain rules about objects and the relationship between them;

- wording of questions about objects and the relationship between them.

Here are some examples of predicates and productive sentences $(\ll i f »)$ :

- bank provides customers with a deposit service;

- bank the final list of possible conditions for the placement of deposits (deposits);

- client chooses the terms of the deposit depending on its needs;

- when placing a deposit, the client needs reliability; maximum profit; capacities add; early withdrawal options; - bank uses the funds placed by the client for other operations (lending, securities, ...);

- it is unprofitable for a bank to provide a high interest rate for a short term;

- it is beneficial for the bank to attract customer funds for a long term; 
- the client is wary of very high interest rates (those that are above the average market);

- customer is wary of periods of 1 year or longer;

- IF the deposit conditions provide for the possibility

of early withdrawal, THEN for such deposit conditions,

there will be a high interest rate;

- IF the deposit agreement is concluded for a period of 1 year or more, THEN the long term must be offset by a high interest rate;

- IF the deposit conditions provide for the possibility of adding funds, THEN the bank is not advisable to place deposits for a long time.

Thus, there is a set of facts about the bank and customers (about the subject area), on the basis of which predicates are built. From these predicates new facts are derived (IF-THEN). Of course, this is the basis for identifying new knowledge in a bank-client relationship.

There are automated tools for formalizing knowledge. For example, the EIDOS system [18].

For formalization, it is necessary to formulate the source data. For example, let's consider the profitability of placing deposit plans depending on a number of parameters.

The parameters are the term of the agreement, the interest rate, the possibility of additional payments, the possibility of early termination of the agreement, the minimum transaction amount.

The source data are given in Table 3 .

Table 3

Initial data for formalizing knowledge

\begin{tabular}{|c|c|c|c|c|c|c|}
\hline No. & $\begin{array}{c}\text { Profitability } \\
\text { degree for } \\
\text { the bank } \\
(1-10)\end{array}$ & $\begin{array}{c}\text { Duration } \\
\text { of agree- } \\
\text { ment }\end{array}$ & $\begin{array}{l}\text { Interest } \\
\text { rate }\end{array}$ & $\begin{array}{c}\text { Possibility of } \\
\text { early termi- } \\
\text { nation of the } \\
\text { contract }\end{array}$ & $\begin{array}{c}\text { Possi- } \\
\text { bility of } \\
\text { adding }\end{array}$ & $\begin{array}{c}\text { Minimum } \\
\text { transaction } \\
\text { amount, } \\
\text { USD }\end{array}$ \\
\hline 1 & 2 & $\begin{array}{l}\text { Less than } \\
1 \text { year }\end{array}$ & 14 & NO & NO & 200 \\
\hline 2 & 1 & $\begin{array}{c}\text { Less than } \\
1 \text { year }\end{array}$ & 14 & NO & YES & 400 \\
\hline 3 & 4 & $\begin{array}{c}1 \text { to } \\
2 \text { years }\end{array}$ & 12.5 & YES & YES & 200 \\
\hline 4 & 7 & $\begin{array}{l}\text { From } \\
4 \text { years }\end{array}$ & 16.5 & NO & NO & 200 \\
\hline 5 & 3 & $\begin{array}{c}\text { Up to } \\
2 \text { years }\end{array}$ & 13.5 & YES & YES & 200 \\
\hline 6 & 5 & $\begin{array}{l}\text { Up to } \\
4 \text { years }\end{array}$ & 15 & NO & YES & 400 \\
\hline 7 & 8 & $\begin{array}{c}\text { From } \\
5 \text { years }\end{array}$ & 17.5 & NO & NO & 400 \\
\hline 8 & 3 & $\begin{array}{l}1 \text { to } 3 \\
\text { years }\end{array}$ & 14 & NO & NO & 400 \\
\hline 9 & 2 & $\begin{array}{l}\text { Less than } \\
2 \text { years }\end{array}$ & 13 & YES & YES & 400 \\
\hline 10 & 4 & $\begin{array}{l}\text { Up to } \\
4 \text { years }\end{array}$ & 15 & YES & YES & 200 \\
\hline
\end{tabular}

The next step in the development of an expert system is the development of qualification scales and gradations, and the development of a training sample, that is, coding of source data using scales and gradations.

Table 4 shows an example of a qualification scale.

Classification scale and its gradations

\begin{tabular}{|c|c|l|}
\hline \multicolumn{1}{|c|}{ Classification scale and its gradations } \\
\hline Code & $\begin{array}{c}\text { Profitability } \\
\text { degree }\end{array}$ & \multicolumn{1}{|c|}{ Name } \\
\hline 1 & $1-3$ & $\begin{array}{l}\text { Minimum profitability, serves only to attract customers } \\
\text { and to build a bank reputation }\end{array}$ \\
\hline 2 & $4-6$ & $\begin{array}{l}\text { Average profitability, the main goal is attracting custo- } \\
\text { mers with income above the average }\end{array}$ \\
\hline 3 & $7-9$ & High profitability - the main goal is the profit of the bank \\
\hline 4 & 10 & Ultra high profitability \\
\hline
\end{tabular}

To build a training sample, descriptive scales must also be formed. An example of such a scale is given in Table 5 .

Tahle 5

Descriptive scales and grades

\begin{tabular}{|c|l|}
\hline Code & \multicolumn{1}{|c|}{ Name (description) } \\
\hline 1 & SHORT - less than 1 year \\
\hline 2 & TERM BELOW AVERAGE - from 1 to 2 years \\
\hline 3 & MEDIUM - 2 to 4 years \\
\hline 4 & LONG-TERM - more than 4 years \\
\hline 5 & MINIMUM RATES - less than $14 \%$ per annum \\
\hline 6 & AVERAGE RATE - 14-16 \% per annum \\
\hline 7 & HIGH RATE - over $16 \%$ per annum \\
\hline 8 & The possibility of early termination is \\
\hline 9 & There is no possibility of early termination \\
\hline 10 & The ability to add funds is \\
\hline 11 & No opportunity to add funds \\
\hline 12 & The minimum amount is 200 USD \\
\hline 13 & The minimum amount is 400 USD \\
\hline
\end{tabular}

Using such scales and gradations, let's form a training sample (Table 6).

\begin{tabular}{|c|c|c|c|c|c|c|}
\hline \multirow[b]{2}{*}{ Object name } & \multirow[b]{2}{*}{$\begin{array}{l}\text { Class } \\
\text { code }\end{array}$} & \multicolumn{5}{|c|}{ Feature codes } \\
\hline & & Term & $\begin{array}{l}\text { Addi- } \\
\text { tion }\end{array}$ & $\begin{array}{l}\text { Early } \\
\text { termi- } \\
\text { nation }\end{array}$ & $\begin{array}{l}\text { Mini- } \\
\text { mum } \\
\text { amount }\end{array}$ & $\begin{array}{l}\text { Interest } \\
\text { rate }\end{array}$ \\
\hline Minimum profitability & 1 & 1,2 & 10,11 & 8,9 & 12 & 6,7 \\
\hline Average profitability & 2 & 2,3 & 11 & 8 & 12,13 & 5,6 \\
\hline High profitability & 3 & 4 & 10,11 & 8,9 & 12,13 & 5 \\
\hline Ultra high profitability & 4 & 4 & 11 & 9 & 13 & 5 \\
\hline Minimum profitability & 1 & 4 & 11 & 8 & 12 & 7 \\
\hline Average profitability & 2 & $2,3,4$ & 10,11 & 9 & 13 & 5,6 \\
\hline
\end{tabular}

Table 6 is not complete, since all possible combinations and variants of conditions are not considered. The table is abridged for demonstration purposes only.

With the help of such a training sample, the system will draw conclusions about the profitability of a bank for depositing depending on the parameters of transactions. 
This approach is the search for a compromise option for the bank and the client: with it, the deposit plan satisfies the needs of the client and brings benefits to the bank. Of course, such criteria are contradictory: the client wants a minimum of restrictions and a maximum of benefits, and it is advisable for a bank to have maximum rights to temporarily dispose of client funds with a minimum fee.

Let's calculate the correlation matrix of knowledge given in Table 7 .

Tahle 7

Knowledge correlation matrix

\begin{tabular}{|c|c|c|c|c|c|}
\hline- & Term & Addition & $\begin{array}{c}\text { Early ter- } \\
\text { mination }\end{array}$ & $\begin{array}{c}\text { Minimum } \\
\text { amount }\end{array}$ & $\begin{array}{c}\text { Interest } \\
\text { rate }\end{array}$ \\
\hline Term & 1 & - & - & - & - \\
\hline Addition & 0.33 & 1 & - & - & - \\
\hline Early termination & -0.012 & -0.667 & 1 & - & - \\
\hline Minimum amount & 0.302 & 0.046 & 0.574 & 1 & - \\
\hline Interest rate & -0.384 & 0.064 & -0.465 & -0.565 & 1 \\
\hline
\end{tabular}

As a result of the metrization of scales, the construction of a correlation matrix, the matrix of absolute frequencies, it becomes possible to correctly and jointly process the results of formalizing descriptions of the source data in these scales and use all arithmetic operations. This allows to use additive integral criteria and reasonably answer the question of how to calculate the total contribution of the features of an object to similarity with certain classes.

Two criteria are used: «Sum of knowledge» and «Semantic resonance of knowledge».

The integral criterion «Sum of knowledge» is the total amount of knowledge contained in the system of factors of various nature that characterize the control object itself, control factors and the environment, about the transition of the object to future target or undesirable states.

The integral criterion is an additive function of the criteria of knowledge:

$$
I_{j}=\left(\overline{I_{i j}}, \overline{L_{i}}\right)
$$

where $M$ - the number of gradations of descriptive scales (features); $I_{i j}$ - the state vector of the $j$-th class; $L_{i}$ - the state vector of the recognized object, including all kinds of factors characterizing the object, the control effects and the environment.

The integral criterion «Semantic resonance of knowledge» is the normalized total amount of knowledge contained in the system of factors of various nature that characterize the control object itself, control factors and the environment, about the transition of the object to future target or undesirable states.

$$
I_{j}=\frac{1}{\sigma_{I} \sigma_{L} M} \sum_{i=1}^{M}\left(I_{i j}-\overline{I_{j}}\right)\left(L_{i}-\bar{L}\right)
$$

where $M$ - the number of gradations of descriptive scales (features); $\bar{I}_{j}$ - the average information content for the class vector; $L$ - the average over the vector of the object; $\sigma_{I}$ - the average deviation of the frequent criteria for knowing the class vector; $\sigma_{L}-$ the average deviation of the vector of the recognized object; $I_{i j}$ - the state vector of the $j$-th class; $L_{i}$ - the state vector of the recognized object, including all kinds of factors characterizing the object, the control effects and the environment.

So, at the stage of formalizing knowledge, a knowledge model is built (in the case of this work, a formal logical model). And also integral criteria of knowledge are calculated, which can be considered a correlation of the state vectors of a particular class (in this case, this is the volume of the deposit portfolio) and the state of the object of study (bank).

\section{SWOT analysis of research results}

Strengths. The strength of this research is the fact that the data for building the optimal strategy is obtained directly from the client. It is understood that in determining the strategy, the requirements and wishes of customers will be taken into account as much as possible to increase satisfaction. Also, due to the vagueness of the evaluation criteria, soft calculations are used, which allows to reduce the level of inaccuracy in the calculations.

Weaknesses. The weak side of the research is the dependence on the size of a commercial bank and the lack of universality. The study is conducted within the framework of a regional bank (which operates within the same area), therefore this technique is not applicable for a world-class commercial bank.

Opportunities. The research prospects are the further creation of an intellectual system that can be put into practice. Such a system would be appropriate for use in small commercial banks both in Ukraine and abroad.

Threats. When implementing the research results, it is necessary, first of all, the time of the bank employees who will provide the initial data for the formation of knowledge. This time is not always possible to use. It is also necessary an agreement with a specific bank, it is difficult enough due to the presence of conservatism in investing.

\section{Conclusions}

1. Surveys of respondents are conducted and statistics on the use of banking services over the past 5 years are collected. Based on this, the most essential criteria for customers of Ukrainian banks are determined. A hierarchy of criteria is built to formalize the problem of bank valuation.

2. Based on the use of customer feedback systems, statistics of calls to the support service, the most popular banking services for customers of Ukrainian banks are identified.

3. Based on the literature analysis it is determined that the basic mathematical apparatus for assessing the quality of the bank and for assessing the degree of customer satisfaction is the model SERVQUAL, SERVPERF. The basic principles of the SERVQUAL model (as the most universal) are taken into account when constructing the hierarchy of criteria.

4. On a specific example (deposit service), the problem of customer expectations and bank capabilities is examined. A project of an intelligent system is built that will seek a compromise solution for a comprehensive criterion for evaluating a bank by customers. Within the framework of this system, an integral criterion is defined that characterizes the control object (bank) and the possibility of its transition to target or undesirable states. Based on the operation of this system, the bank management can make 
decisions regarding the bank's development strategy. In a further study, it is proposed to develop a method for the optimal distribution of domestic investment based on an indicator of this integral criterion. That is, in which criteria from the hierarchy of the bank's valuation should be invested, and to what extent, in order to be able to transfer the control object to the desired state.

\section{References}

1. Senaar, K. (2019). AI in Banking - Analysis of America's top 7 Banks. Emerj Artificial Intelligence Research. Available at: https://emerj.com/ai-sector-overviews/ai-in-banking-analysis/

2. Smale, T. (2018). 5 Ways Artificial Intelligence is Already Transforming the Banking Industry. Enterpreneur. Available at: https://www.entrepreneur.com/article/319921

3. Burtsev, M., Kairova, O. (2013). iPavlov research platform. Available at: http://ipavlovai/

4. Butenko, E. D. (2018). Artificial intelligence in banks today: Experience and perspectives. Finance and Credit, 24 (1), 143-153. doi: http://doi.org/10.24891/fc.24.1.143

5. Chi Cui, C., Lewis, B. R., Park, W. (2003). Service quality measurement in the banking sector in South Korea. International Journal of Bank Marketing, 21 (4), 191-201. doi: http://doi.org/ 10.1108/02652320310479187

6. Quyet, T. V., Vinh, N. Q., Chang, T. (2015). Service Quality Effects on Customer Satisfaction in Banking Industry. International Journal of $u$ - and e-Service, Science and Technology, 8 (8), 199-206. doi: http://doi.org/10.14257/ijunesst.2015.8.8.20

7. Yavas, U., Bilgin, Z., Shemwell, D. J. (1997). Service quality in the banking sector in an emerging economy: a consumer survey. International Journal of Bank Marketing, 15 (6), 217-223. doi: http://doi.org/10.1108/02652329710184442

8. Mohiuddin, M. (2014). Trend and Development of E-Banking: A Study on Bangladesh. IOSR Journal of Business and Management, 16 (5), 16-24. doi: http://doi.org/10.9790/487x-16521624

9. Maslennikova, D. S. (2009). Ocenka nadezhnosti banka: celi i kriterii dlia partnerov i dlia samogo banka. Zhurnal nauchnykh publikacii. Available at: http://jurnal.org/articles/2009/ ekon68.html
10. Isaev, R. A. (2011). Sposoby obespecheniia i uluchsheniia kachestva obsluzhivaniia klientov banka. Metody menedzhmenta kachestva, 6, 54-58.

11. Ferreira, F. A. F., Spahr, R. W., Santos, S. P., Rodrigues, P. M. M (2010). A multiple criteria framework to evaluate bank branch potential attractiveness. Banko de Portugal, 10. Available at: https://ideas.repec.org/p/ptu/wpaper/w201010.html

12. Andreeva, O. S., Nazmutdinova, E. V. (2015). Ocenka privlekatelnosti kommercheskoi organizacii dlia korporativnykh klientov. Ekonomika i predprinimatelstvo, 10, 3-6.

13. Tretiakova, O. (2001). Kak vybiraiut banki. Vestnik Uralskogo instituta prikladnoi politiki i ekonomiki, 21-25.

14. Lau, M. M., Cheung, R., Lam, A. Y. C., Chu, Y. T. (2013) Measuring Service Quality in the Banking Industry: A Hong Kong Based Study. Contemporary Management Research, 9 (3), 263-282. doi: http://doi.org/10.7903/cmr.11060

15. Carnasciali, A. M., Delazari, L. (2010). Spatial Decision Support System for Bank-Industry Based on GIS and Expert Systems Integration. Decision Support Systems. doi: http:// doi.org/10.5772/39460

16. De Marco, M., Salcioli, G., Fedegari, F. (1993). Bank Tutor: an expert system for treasury management. Proceedings of IEEE Systems Man and Cybernetics Conference - SMC. doi: http:// doi.org/10.1109/icsmc.1993.384726

17. Dabahian, D., Godlevskyi, M. (2017). Bank Attractiveness Evaluation Method Based on Soft Computing in the Analytic Hierarchy Process. ICTERI-2018. Kyiv, 8-15.

18. Ostroukh, A. V., Surkova, I. E. (2015). Intellektualnye informacionnye sistemy i tekhnologii. Krasnoiarsk: Nauchno-innovacionnii centr, 2015. Available at: http://lib.madi.ru/fel/fel1/ fel16S062.pdf

19. Lucenko, E. V. (2016). Sintez adaptivnykh intellektualnykh izmeritelnykh sistem s primeneniem ASK-analiza. Nauchnii zhurnal KubGAU, 116 (2), 1-12.

Dabahian Davyd, Postgraduate Student, Department of Software Engineering and Management Information Technologies, National Technical University «Kharkiv Polytechnic Institute», Ukraine, e-mail: vstup_piitu@gmail.com, ORCID: http://orcid.org/00000002-5311-2108 